Section Editor

Mitchell S.V. Elkind, MD, MS

\section{Teaching NeuroImages: \\ Dual-phase 3D multislice CT angiography for the detection of intracranial pseudoaneurysm}

K.-S. Jang, MD, PhD

D.-K. Jang, MD

Y.-M. Han, MD, PhD

A.H. Lee, MD, PhD

Y.S. Park, MD, PhD

Address correspondence and reprint requests to Dr. Dong-Kyu Jang, Department of

Neurosurgery, Incheon St. Mary's Hospital, 665 Bupyung-Dong, Bupyung-Gu, Incheon, Korea argus3620@gmail.com

Figure Dual-phase 3-dimensional multislice CT angiography and pathology of an intracranial pseudoaneurysm
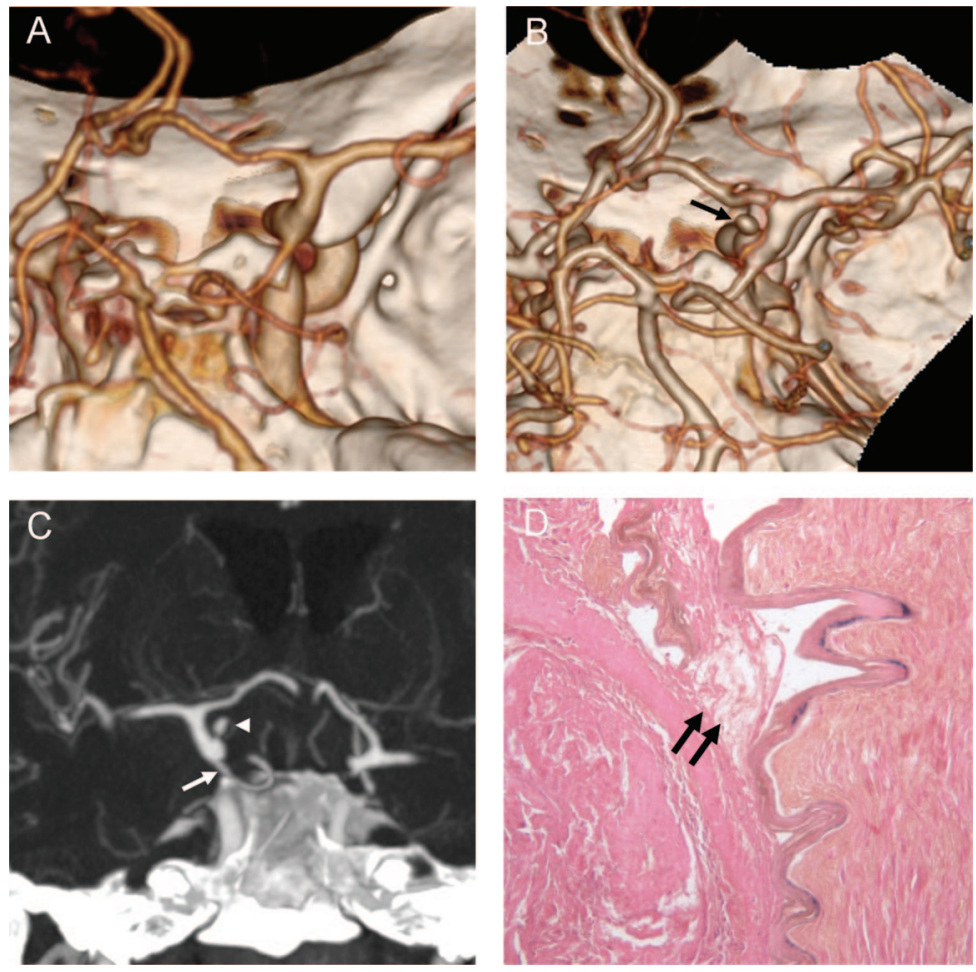

(A) An early-arterial-phase 3-dimensional CT angiogram shows no aneurysm on the right internal carotid artery. (B, C) A dorsal wall aneurysm in the right ICA on a late-arterial-phase 3-dimensional CT angiogram ( $\mathrm{B}$, black arrow) and on a coronal maximal intensity projection image (C: arrowhead, pseudoaneurysm; white arrow, fetal-type posterior cerebral artery). (D) Aneurysm wall pathology shows rupture of the internal elastic lamina (double black arrows) (D: elastic stain, $\times 200)$.

A 45-year-old woman was diagnosed with a subarachnoid hemorrhage. Dual-phase 3-dimensional CT angiography (12 and 23 seconds) showed no aneurysm in the early arterial phase (figure, A), but revealed a dorsal-wall aneurysm in the right internal carotid artery on a 3-dimensional image (figure, B) and a maximal intensity projection image (figure, C) in late arterial phase. This aneurysm was trapped with a bypass surgery, and pathologically confirmed as a pseudoaneurysm (figure, D). Dualphase multislice $\mathrm{CT}$ is a valuable tool to confirm an ongoing bleeding site, ${ }^{1,2}$ which may be a critical clue for the treatment strategy of an intracranial pseudoaneurysm.

\section{REFERENCES}

1. Kluner C, Rogalla P, Gralla O, Elgeti T, Hamm B, Kroencke T. Value of dual-phase multislice CT prior to minimally invasive therapy of iatrogenic renal injuries. J Endovasc Ther 2005;12:461-468.

2. Sadick M, Rohrl B, Schnulle P, Duber C, Diehl SJ. Multislice CT-angiography in percutaneous post-interventional hematuria and kidney bleeding: Influence of diagnostic outcome on therapeutic patient management. Preliminary results Arch Med Res 2007;38:126-132.

From the Departments of Neurosurgery (K.-S.J., D.-K.J., Y.-M.H., Y.S.P.) and Pathology (A.H.L.), Incheon St. Mary's Hospital, College of Medicine, The Catholic University of Korea, Incheon, Korea.

Disclosure: The authors report no disclosures. 


\section{Neurology}

\section{Teaching NeuroImages: Dual-phase 3D multislice CT angiography for the detection of intracranial pseudoaneurysm}

K.-S. Jang, D.-K. Jang, Y.-M. Han, et al.

Neurology 2011;76; 101

DOI 10.1212/WNL.0b013e31821a4495

\section{This information is current as of May 16, 2011}

\section{Updated Information \& Services}

References

Subspecialty Collections

Permissions \& Licensing

\section{Reprints}

including high resolution figures, can be found at: http://n.neurology.org/content/76/20/e101.full

This article cites 2 articles, 0 of which you can access for free at: http://n.neurology.org/content/76/20/e101.full\#ref-list-1

This article, along with others on similar topics, appears in the following collection(s):

All Cerebrovascular disease/Stroke

http://n.neurology.org/cgi/collection/all_cerebrovascular_disease_strok e

All Imaging

http://n.neurology.org/cgi/collection/all_imaging

Carotid artery dissection

http://n.neurology.org/cgi/collection/carotid_artery_dissection CT

http://n.neurology.org/cgi/collection/ct

Subarachnoid hemorrhage

http://n.neurology.org/cgi/collection/subarachnoid_hemorrhage

Information about reproducing this article in parts (figures,tables) or in its entirety can be found online at:

http://www.neurology.org/about/about_the_journal\#permissions

Information about ordering reprints can be found online:

http://n.neurology.org/subscribers/advertise

Neurology ${ }^{\circledR}$ is the official journal of the American Academy of Neurology. Published continuously since 1951, it is now a weekly with 48 issues per year. Copyright Copyright (? 2011 by AAN Enterprises, Inc.. All rights reserved. Print ISSN: 0028-3878. Online ISSN: 1526-632X.

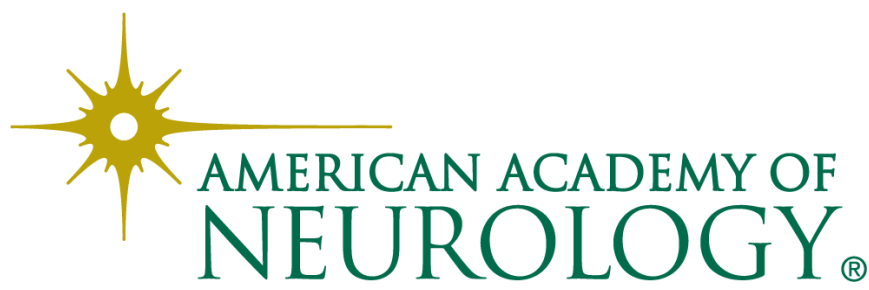

